\title{
MANAGING, TRACKING AND COMMUNICATING BOARD DIVERSITY
}

Marie Josée Roy, University Laval, Quebec city, Quebec, Canada Marie Christine Roy, University Laval, Quebec city, Quebec, Canada

dx.doi.org/10.18374/IJSM-20-1.1

\begin{abstract}
Demands for increased board diversity have been mounting over the last ten years. Governance activists, corporate shareholders and government regulators are asking companies to better address these issues and to disclose relevant information about board diversity and the policies they have implemented to support their efforts. Based on an analysis of disclosures made in the proxy circulars of 60 leading Canadian listed companies, our study investigates what are the specific dimensions of board diversity being addressed, and what are the systems implemented to better manage and track those dimensions. Our study particularly focuses on knowledge and competency diversity and the skills matrix boards have been using to disclose its boards' qualifications. Our results help shed some light onto the evolution of diversity practices in the recent years. We also discuss alternative processes that firms can implement to improve the competency profile of their boards.
\end{abstract}

Keywords: Board of directors, board diversity, skills matrix. 